\title{
Gender Relation Concept: Perspective of Alqur'an
}

\author{
Faisar Ananda Arfa ${ }^{1}$, Heri Firmansyah ${ }^{2}$ \\ 1,2 Fakultas Syari'ab dan Hukum Universitas Islam Negeri Sumatera Utara Medan \\ e-mail: faisar_nanda@yahoo.co.id
}

\begin{abstract}
ABSTRAK. Dalam masyarakat agama akan selalu terjadi perdebatan antara kelompok yang bertaban dengan teks sebagaimana adanya dengan pihak-pibak yang mencoba membaca teks dalam konteks dan membuatnya selaras dengan perkembangan paradigma baru dalam kehidupan kekinian. Salah satu topik yang merefleksikan fenomena di atas adalah ketika wacana gender yang adalah problematika kehidupan cosmopolitan modern dihadapkan dengan teks-teks suci yang telah berusia berabad-abad yang lalu. Tidaklah mengherankan bila kemudian terjadi perdebatan yang serius tentang kemampuan masyarakat agama di dalam merespon issu gender ini. Artikel ini berusaha untuk mengungkapkan pengkajian Islam modern dengan mempelajari suatu pendekatan baru yang popular dengan istilah pendekatan gender di dalam melakukan analisa terhadap ayat-ayat maupun hadis nabi dan istinbat bukum terutama di dalam menggambarkan posisi dan peranan kaum wanita serta bubungan mereka dengan kaum laki-laki. Dalam artikel ini akan ditemukan secara jelas babwa Konsep relasi gender di dalam Alquran merefleksikan dua kesan yang berbeda secara theologies dan sosiologis.
\end{abstract}

\begin{abstract}
In religious societies there will always be debates between groups that persist with the text as it is with parties who try to read the text in context and make it in harmony with the development of new paradigms in contemporary life. One topic that reflects the above phenomenon is when gender discourse is a problem of modern cosmopolitan life confronted with sacred texts that have been centuries old. It is not surprising then that serious debate ensues about the ability of religious communities to respond to this gender issue. This article seeks to express the study of modern Islam by studying a new app roach that is popular with the term gender approach in analyzing the verses and traditions of the prophet and legal istinbat especially in describing the position and role of women and their relationship with men. In this article it will be clearly found that the concept of gender relations in the Koran reflects two different theological and sociological impressions.
\end{abstract}

Keyword: Gender, Relation, Concept, Perspective, Al-Qur’an.

\section{INTRODUCTION}

The main problem that arises when talking about modern issues in the perspectives of religions is the limitations of texts confronting the reality that occurs in the lives of adherents. Religious texts that descended on hundreds or thousands of centuries ago would of course have difficulty responding to the dynamics that occur in a developing society when its adherents try to persevere with existing texts. Therefore, in any religious society there is always a tug-of-war between the surviving group and the texts and those who try to read the text in context and make it align with the development of a new paradigm in contemporary life.

One of the topics that reflects the above phenomenon is when the gender discourse which is the problematic of modern cosmopolitan life is faced with centuries-old sacred texts. It is not surprising that then there is a serious debate about the ability of religious communities to respond to this gender issue. For those who want to persist with the sacred text literally then they see that the existing situation must be harmonized with the willingness of the available text. If it is not possible then the situation is to blame, not the texts that are tampered with. Of course this attitude leads to a separation between the text on the one hand 
and the reality on the other. On the other hand religious social thinkers try to present a new point of view that makes it possible to align the text with reality. The offer is to retain the existing text but stress the context of the existing text, then draw a connection between the old reality and the present reality and then offer a fresh conclusion in an effort to bridge the old text with a new reality. This business despite controversy, but along with the passage of time finally get attention as well as understanding the alternative.

Religion is one of the elements that shape the culture of a society. The way a society treats their women is a reflection of their understanding of religious texts. Historically, therefore, shows that people's treatment of women fluctuates according to the factors that influence the outlook. World religions such as Judaism, Christianity, Buddhism, Zoroastrianism and Islam represent this prototype. Past Greek society treats women according to their hierarchy. The nobles are kept in the palaces while the proletariat is bought and sold. For the housekeeper is fully controlled by men. They have no civil rights including inheritance rights. Roman civilization gives full power to the father who will then move on to her husband when married. The Emperor Constantine gave little limited ownership rights to women. Hindu and Chinese civilization burns a wife alive if her husband dies. In a Jewish society the woman's dignity is equivalent to a maid. They consider women the source of the curse for being the cause of Adam being expelled from heaven. In the eyes of female religious leaders Christian is a Devil's weapon to mislead. Human. The European battle century until 1882 the British woman had no full ownership of property and the right to prosecute. In America women have no right to vote except for the last few years. Even though Islamic societies claim to have given women a good position but in modern measures some of its legal rules are still seen as subordinating to women.

The texts that are believed to be sacred texts by their followers from the past to the present certainly provide a relatively different understanding from time to time. In gender discourse that is often interpreted by differences between men and women -without biological connotation-which is a social formation. Gender relations are a collection of rules, traditions and mutual social relationships in societies and cultures that define feminine and masculine boundaries.

Some studies show for example Christians in the Middle East have a more positive and more liberal view of women and allow them to play a more active role in the church than Christians in Rome and Byzantium. Previously Egyptian and Syrian Christians emphasized the female aspect of God (God the Father and Mother God), something that is considered heretic in the dominating Christian concept. Later this is prohibited by the church as well as the role of women is limited. In the Hindu teachings Sarassamuccaya explains about the very limited position of women only as wives who must obey husbands and if they do not obey will get a curse.

In Sarassamuccaya, the role of women never reaches a conclusion. They wobble up to the end of the story. The Sarassamuccaya text is a male plot text. Women are only given the role of extras. Role as complement in every episode. Sarassamucaya is a great text that is patriarchal and full of inconsistencies.

All religions have the same experience of having difficulty in reading the sacred texts in the present context. Therefore, a critical attitude to the sacred text is needed in order to provide a more harmonious understanding of the times. One of the methods required in reading the sacred text is the hermeneutic method, ie reading the text in context and then looking for alternative interpretations that are more in tune with the present demands.

If the clerics are very tied to the text, then the impression will appear religion has been abandoned by his followers because the behavior they show is not in accordance with the demands of the existing text. Therefore, the ability to read text in context is needed by the 
clergy. A text must be considered sacred in the sense that its texts can not accept change despite a letter, but the understanding of the text requires a reinterpretation from time to time. The mistake so far is that often among clerics there is a perception of equality between the sacred text and the interpretation made by its predecessors.

How to read the text is strongly influenced by the background when the text is read or interpreted by readers. Therefore, what needs to be developed is the need to build a new paradigm among clerics in addressing religious texts of the past in response to emerging issues including gender issues which have recently become quite a tool to challenge the establishment of sacred texts and their interpretations. Gender is a matter of interest to recent Islamic scholars. It is given that the Islamic literature of the classical period such as ushul fiqh, fiqh or tafsir (exegesis) never used such approach in constructing his theory, nor in interpreting Qur'anic verses. Of course, because women's issues in Islamic teachings are considered ideal, perfect and final so no other approach is required. Classical Islamic literature always portraying Islam as lifting the dignity of women to the highest level, an achievement that no religion has ever done in this world.

The development of modern Islamic studies led Islamic scholars to study a popular new approach with the term gender approach in analyzing the verses and hadiths of prophets and istinbat\} law, especially in describing the position and role of women and their relationship with men. The results obtained with this gender approach seem to differ from the interpretations that have been deemed to be established so far, causing controversy among the public.

\section{Gender Definition}

It must be understood that the term gender is not in the classical literature of Islam. This term comes from the western world, so impressive as something foreign. Therefore, understanding of gender analysis is also often misinterpretation. This is because people often associate it with issues of the sex of men and women. No wonder there are some people who say where maybe men and women alike. It arises because they think in the biological context of sex. Of course their opinion is correct because it is impossible to equate between male and female sex.

But gender has its own understanding. Gender does not talk about gender but more on the concept of sex, such as how to become a woman; what is appropriate and inappropriate to do; and so on so as to form a cultural concept that shapes the behavior of a woman and a man. The question that arises is whether the concept is something that is established and should not change; whether the concept is either an apocalypse or a human thought. Gender is defined as a sociocultural construction that distinguishes both masculine and feminine characteristics. Gender differs from sex or sex that distinguishes men from women.

Research using a feminist methodology will result in an analysis that shows how women are accepted by society, as well as how women perceive community. Research with a feminist methodology is expected to result in an in-depth analysis involving the experience and sounds of women, in which a feminist conscious will choose the attitudes and alignments to women. Research with a feminist methodology will put women's experience equally and equally as important as men's experience-a difficult thing to do in the positivist paradigm-is expected to contribute more in-depth data to the consideration of more women-friendly public policy making.

This research topic is important to explain the understanding of gender phenomena related to the treatment and the role of women in society in all aspects of their life. One study worthy of attention is the research of Amina Wadud who seeks to breakthrough to break the injustice of interpretation of women. This effort is important to eliminate the imbalance of 
gender relations, men with women among Muslims. It is this inequality that has overwhelmed the tremendous potential of women.

Previous works by Fazlur Rahman, Fatima Mernissi, Leila Ahmed, Martin Buber, Khaled Abou El-Fadl, and Majid Fakhry have conducted similar research. Rahman has introduced a method of holistic interpretation that emphasizes the study of the normative aspects of Islamic teaching. Holistic theory offers a method of coherent Qur'anic understanding called the hermenic method. Wadud adopted the Rahman method with the term double movement, and the thematic method of the verse which aims to reduce the interpretation subjetifitas.

Fatimah Mernissi focuses on the cultural-historical aspects analyzed through the context of the descending verse and the condition of the culture of society in an area with others such as the Arabic mind with existing cultural influences will have an effect on worship. In his work Women and Islam: An Historical and Theological Inquiry criticizes the mufassirs who interpret the Qur'anic verses are inconsistent with a sense of justice towards the woman displayed by the Messenger, who never turns violent towards his wives.

Leila Ahmed focuses on the phenomenon of Muslim understanding groups. He is interested in the phenomenon of ritual and culture of society that affects the treatment on the role of women. There is a difference of common sense understanding of each region. According to him, Islam has an important role in the transformation of Arab religious social views so that it is in line with the traditions of the Middle East and Mediterranean regions.

Khaled Abou alFadl offers the concept of interpretive authority. No one has the right to claim his most correct interpretation because it feels this from God. Fakhri Madjid with ethical toeri based all the problems to the moral message of the Qur'an. Although the definition of ethics of each individual with a cultural background will be different

The research method used by Amina Wadud is by using linguistic-hermenutic approach, with philological analysis or content analysis holistically. Wadud uses the double movement theory and the thematic approach of Fazlur Rahman to explain the verses about women. Wadud also uses Quranic interpretation with quran. Wadud analyzes the texts of Qur'anic verses by focusing on the multiple meaningful compositions of the Qur'an with the purpose of describing the meaning of the text by analyzing the text prior (perception, state, background) of the interpretation of women.

So diverse the analysis applied in the issue of gender relations in khasanah keilmuwan Islam. Therefore the relationship between men and women is a topic of discussion that is still interesting to discuss. As a religion that encompasses all aspects of Islamic society life is also involved in the issue of gender relations. Many already thought that poured by Islamic thinkers related to the above topic. But what is interesting is when we try to restore the concept of gender relations from the point of view of the Qur'an itself. This becomes interesting to review as methodologically this study is conducted at the source level. As the first and main source of the Islamic teachings of the Qur'an in many of its sacred texts, of course, there is talk about the relationship between men and women. As the first source of Islamic teachings, of course, the Qur'an is clean information from the interpretation of human thought so that the result will be more felt origin.

\section{METHODOLOGICAL ISSUES}

To make this study clearer, we will first explain what method will be used in this discussion. Methodologically, this study uses the method of tafisr mawdu ${ }^{\wedge}$ yi which works as follows. Method Tafsir Mawdhu'i (thematic exegesis). The method pursued by a mufassir by 
collecting all verses of the Qur'an that talk about a topic and lead to one sense and one purpose, even though the verse of the verse is different and spread in various letters in the Qur'an and also different times and places of descent.

The step of applying the maudhu'i method is formulated by the following steps: Selecting the theme to be studied and then collecting all the Qur'anic verses relating to the theme studied, determining the sequence of verses collected with asbab nuzulnya if any, explaining munasabah between verses of the verse on each each of its letters and the relation of those verses with subsequent verses, makes systematic study in a systematic and complete framework. ${ }^{1}$

Quraish Shihab has written a commentary with this mawdhui method in a book entitled Insight of the Qur'an and He has specifically written on a topic about Women. In the article Quraish tries to explain about the Origin of Women's Events and Women's Rights. ${ }^{2}$

This paper itself will try to see the gender relation from the perspective of the Qur'an, a theme more specific than the title written by Quraish Shihab on women, Gender relationship is more on the issue of relationships that occur between men and women not in its connotation as sex differences but rather on gender differences. It is rather difficult to discuss this because the term gender is very difficult to find literally in the Qur'an. It seems that the author must also borrow the style of interpretation ahkam in approaching the issue of this gender relation.

\section{FINDINGS AND DISCUSSION}

To facilitate discussion of gender relations some verses may still be considered to represent the theme of gender relations in the Qur'an as follows:

1. Surah $51: 56$

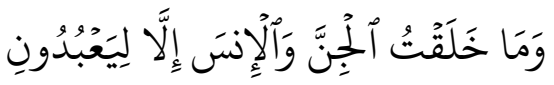

And I did not create jinn and men but to serve them to Me.

2. Surah $49: 13$

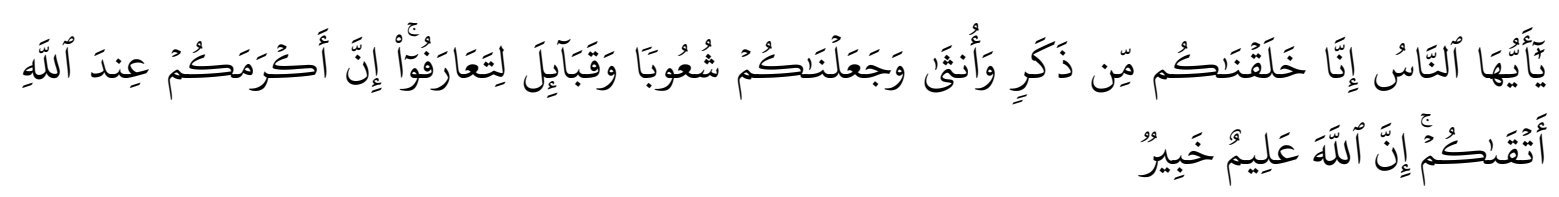

O mankind, We created you from a man and a woman, and made you nation and tribe so that you may know one another. Verily the most honorable among you by Allah is the most pious among you. Allah is the Knower, the Knower.

3. Surah $16: 97$

1 Ali Hasan Al-Aridl, Sejarah dan Metodologi Tafsir (Jakarta :PT Raja Grafindo Persada,1994), p. 78-92.

2 M.Quraisy Shihab, Wawasan Alquran:Tafisr Maudhu'i Atas Pelbagai Persoalan umat (Bandung: Mizan, 1996), p. 296-318. 


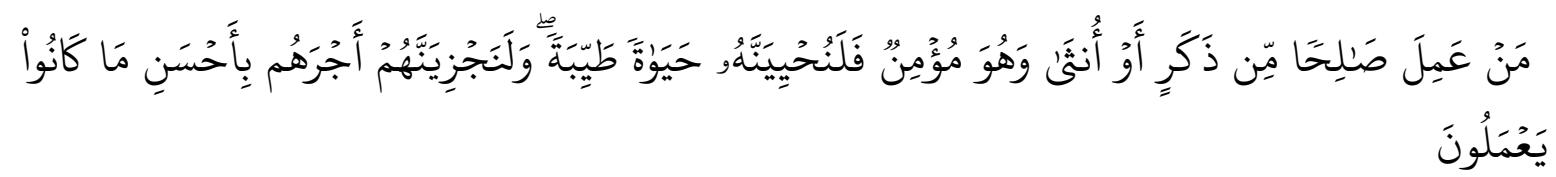

Whoever works righteous deeds, both men and women in a state of faith, then surely we will give bim a good life and verily we will reward them with a better reward from what they have done.

It is emphasized in this verse that men and women in Islam get the same reward and that righteous deeds must be accompanied by faith.

4. Surah 2:30

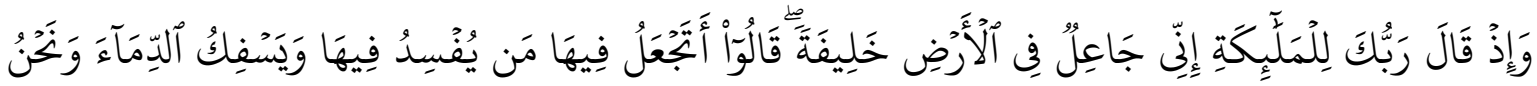

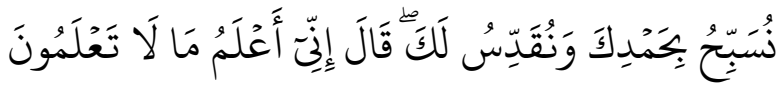

Remember when your Lord said to the angels: "I will make a caliph in the earth." they say: "Why do you want to make the (Caliph) on earth the one who will make damage to him and shed blood, whereas we always glorify by praising You and purifying You?" The Lord said: "Verily I know what you do not know."

5. Surab 6: 165

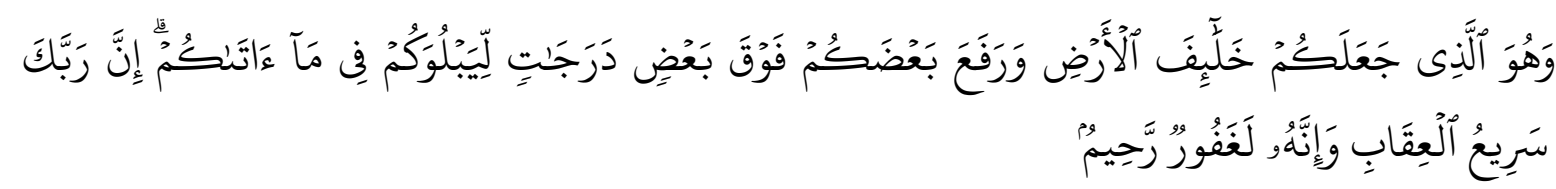

He is He who made you the rulers of the earth, and he exalts one part of you above a few degrees, to test you of what He has given you. Verily thy Lord is very torture, and verily, he is Oft-Forgiving, Most Merciful.

6. Surah 7: 172

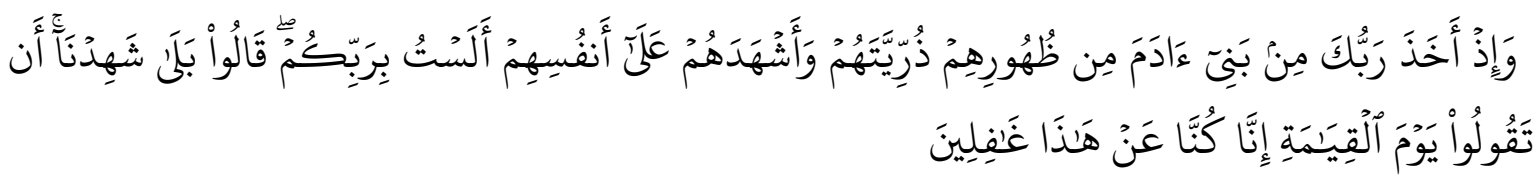

And (remember), when your Lord took the offspring of the sons of Adam from their sobbi and God took witness of their souls (saying): "Am I not This your Lord?" they replied: "True (You are our Tuban), we are witnesses". (We do so) so that on the Day of Resurrection you do not say: "We (the People of Adam) are the guilty of This (the unity of God)",

7. Surah 17:70

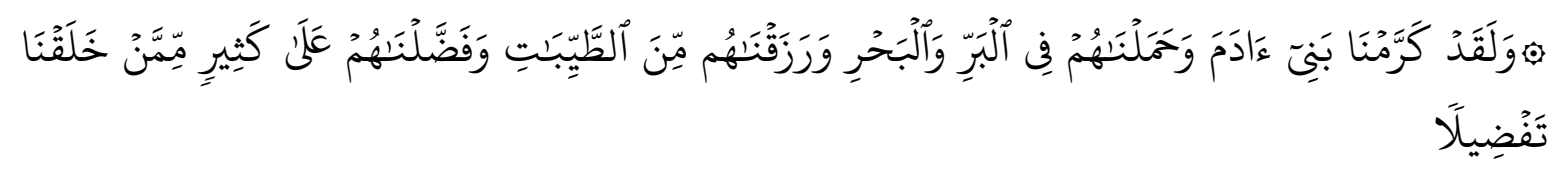

And verily $W$ e have honored the children of Adam, we transport them on land and in the oceans, we give them sustenance from the good and we exaggerate them with the perfect advantages over most of the creatures we have created. 
8. Surah 5:89

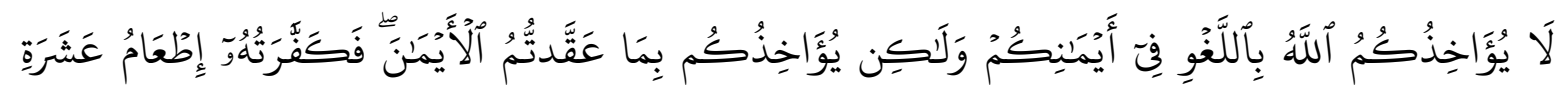

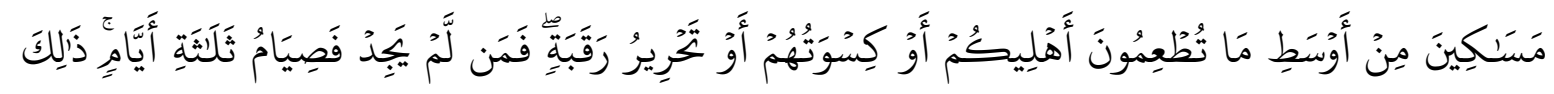

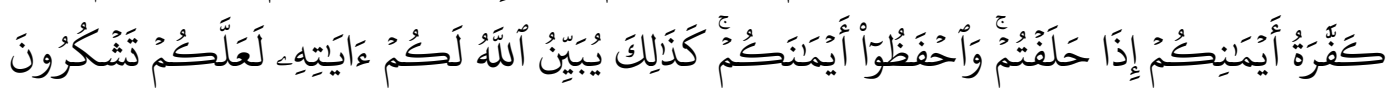

God does not punish you for your unbreakable oaths, but he punishes you for your deliberate oaths. The kaffarat (breaking) the oath, then, is feeding the ten poor, from the food you used to give to your family, or to give Clothes to them or to free a slave. whoever is not able to do such, then kaffaratny a fasting for three days. that is the keaffarat of your oaths if you swear (and you violate). and keep your oath. Thus Allah gives you His commandments to give thanks (to Him).

9. Surah $60: 12$

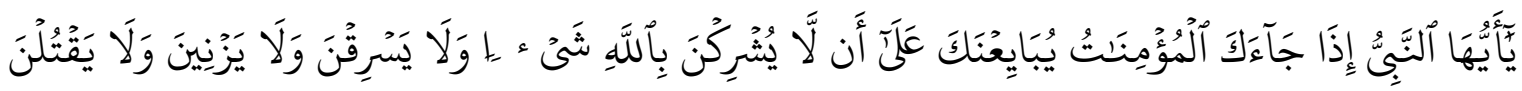

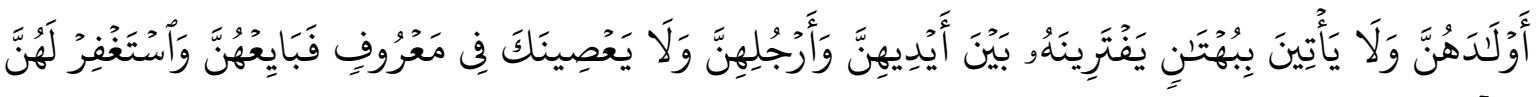

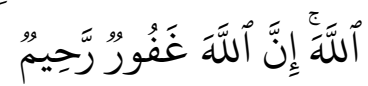

O Prophet, when the faithful women come to you to make a pledge, that they will not associate partners with Allah, will not steal, nor commit adultery, will not kill their children, will not lie that they are made between hands and their feet and will not rebuke you in good matters. So accept their faithful promises and ask forgiveness of Allah for them. Allah is Forgiving, Merciful.

10. Surah 2:35

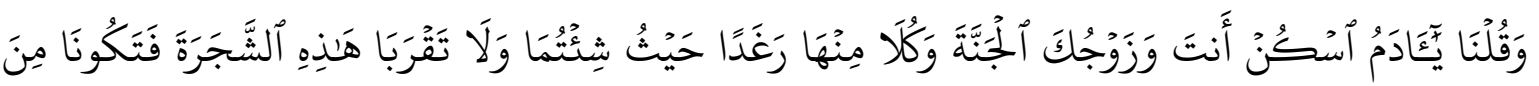
ألظظّلِمِينَ

And we said: "O Adam, have you and your wife this heaven, and eat the many good foods wherever you please, and approach not this tree, which causes you to be among those who do wrong.

11. Surah $7: 20$

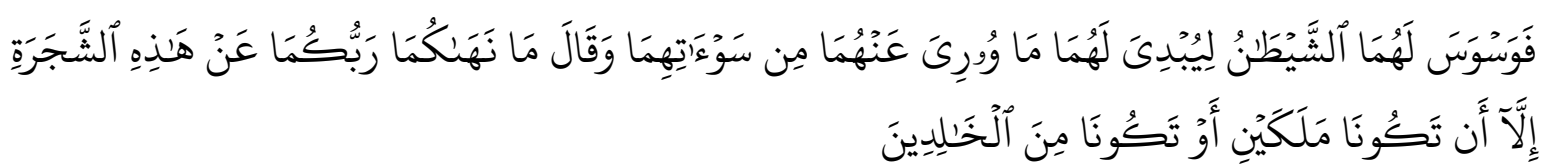

So Shaytan whispered evil thoughts to both of them to reveal to them what was hidden from them that was his private parts and Satan said: "Your Lord did not forbid you and approached this tree, but that both of you will not be angels or not to be eternal (in heaven) ".

12. Surah $7: 22-23$

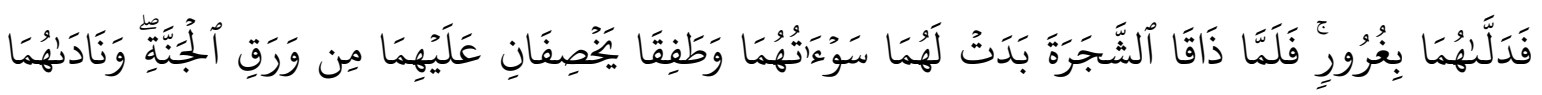

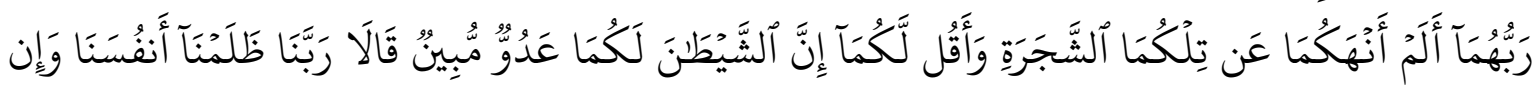

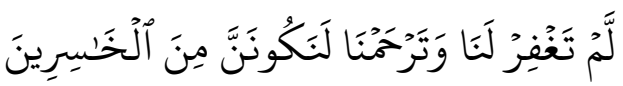

So Shaytan persuaded the two (to eat the fruit) by deceit. when both have tasted the fruit of the wood, it appears to both its aurat-auratnya, and start covering it with the leaves of heaven. Then their Lord called them: 
"Did I not forbid you both from the tree and say to you," Surely that shaitan is a real enemy to you both?" Both said: "Our Lord, we have wronged ourselves, and if You do not forgive us and grant us mercy, surely we must be among the losers

13. Surah 2: 187

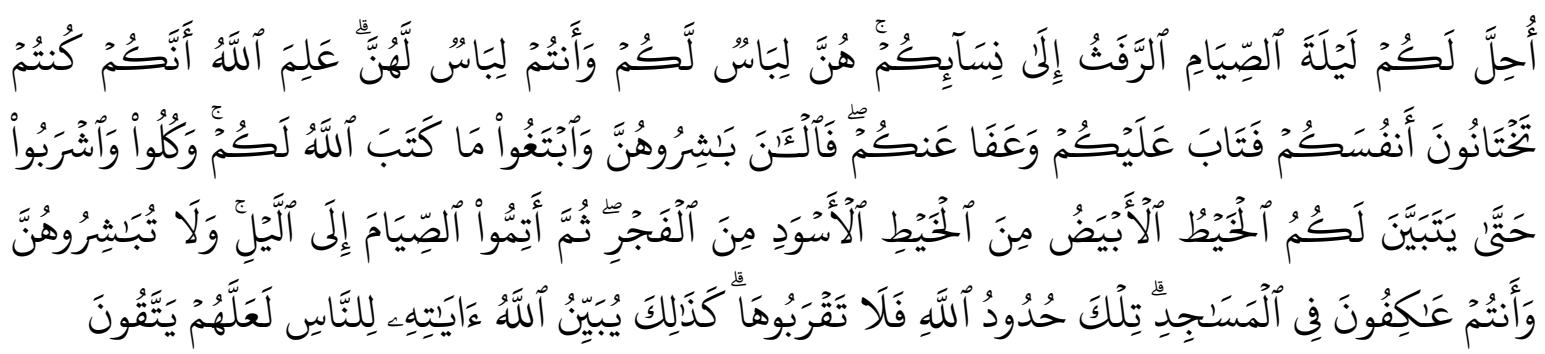

It is permissible for you on the night of the fasting month to mix with your wives; they are Clothes to you, and you are their Clothes. Allah knows that you can not hold your lusts, therefore God forgive you and give you forgiveness. So now mix them up and follow what Allah has ordained for you, and eat to the light you thread white from the black thread of dawn. Then complete the fast until (coming) night, (but) do not interfere with them, while you berik'tikaf in the mosque. That is the probibition of Allah, so do not approach him. Thus Allah explains His verses to man, that they may be cautious.

14. Surah 2: 195

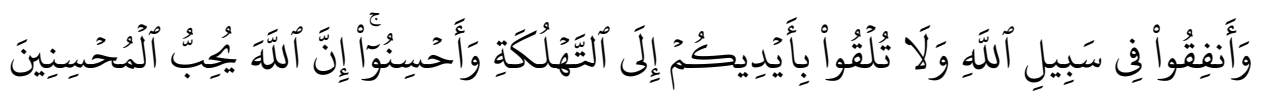

And spend (your treasures) in the way of Allah, and do not throw yourself into perdition, and do good, for Allah loves those who do good.

15. Surah 4: 124

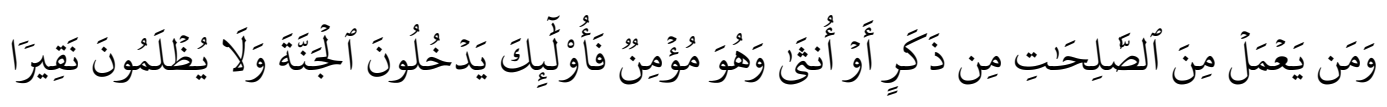

Whoever works righteous deeds, both male and female, he is a believer, so they enter Paradise and they are not persecuted even the slightest.

\section{Surah 16: 97}

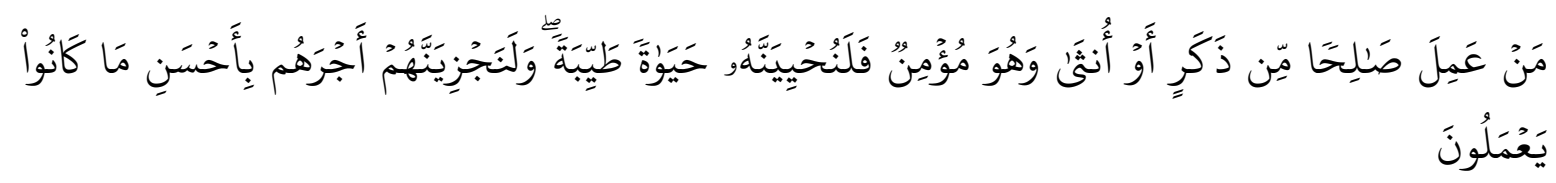

Whoever works righteous deeds, both men and women in a state of faith, then surely we will give him a good life and We will surely reward them with a better reward from what they have done.

It is emphasized in this verse that men and women in Islam get the same reward and that righteous deeds must be accompanied by faith.

17. Surah 40: 40

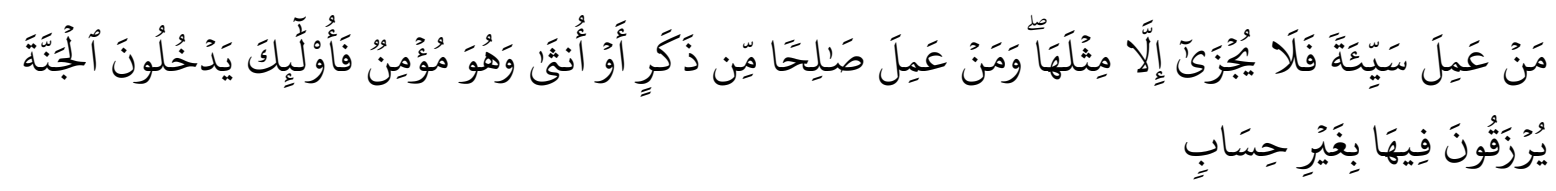

Whoever does evil, then he will not be refitted but comparable with the evil. and whoever works righteous deeds both men and women while he is in a state of faith, Then they will go to heaven, they are given rezki in it without reckoning. 


\section{A. Paragraph Exegesis Related to Gender Relations}

To facilitate the study of gender from the perspective of the Qur'an with this exegesis approach, the authors will discuss this issue in several sub-topics by focusing on the issue of gender relations. The Qur'an impresses the paradox in addressing gender relations between men and women. From the perspective of theologies the Qur'an explains in some of his verses about equality between men and women in the sight of God. But on the sociological level of politics and the law of the Qur'an implies men are above women's level.

\section{Male and female are equal beings}

The Qur'an explicitly suggests that the position of man and woman in the eyes of God is equal. In the capacity of human beings as God's creatures, there is no difference between men and women. Both have the same opportunity to be God's pious servant. The devotion does not recognize gender, ethnicity, certain nations or even the privilege of Arabs than any other nation in perfecting the level of piety. Verse 13 of the letter Alhujurat states clearly the position with the statement:

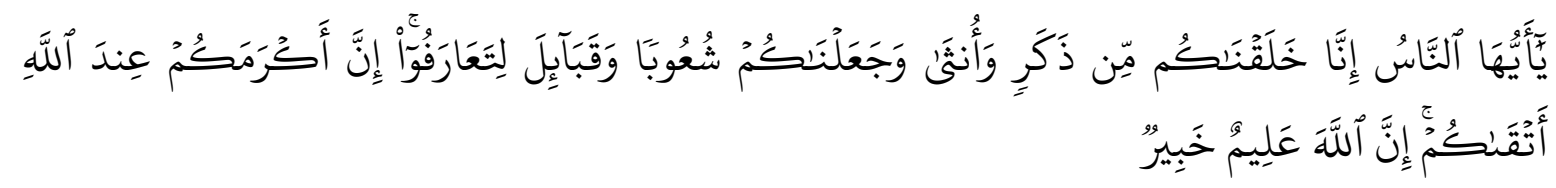

O mankind, We created you from a man and a woman, and made you nation and tribe so that you may know one another. Verily the most honorable among you by Allab is the most pious among you. Allah is the Knower, the Knower.

This verse explains, $\mathrm{O}$ man we have created you from a man and a woman. Every one of you is a descendant of a father and one mother therefore there is no advantage among you from the aspect of the offspring. Then we make you nation and ethnic tribe so that you can easily know each other not to pride themselves with it. Because God gives the judgment that the most noble among men is the most pious among them. ${ }^{3}$

In the capacity as 'abid, men and women will each receive an award from God according to their level of devotion. This is in accordance with His word in the letter alNahl 97.

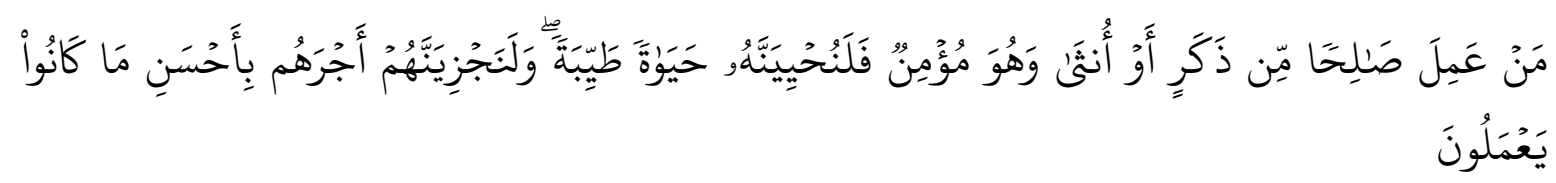

Whoever works righteous deeds, both men and women in a state of faith, Then We will indeed give him a good life and We will surely reward them with a better reward from what they have done.

The 32nd verse of the letter alnisa describes the efforts made by men and women and the opportunities they find equally appropriate to the business they are working on

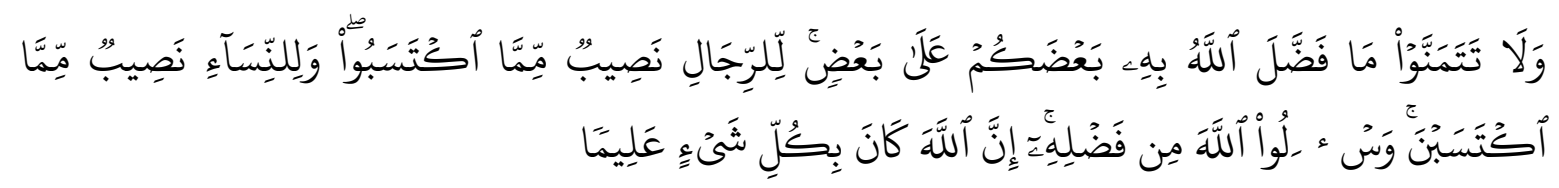

And do not be jealous of what Allah has granted to some of you more than some of the others. (for) for men there is a share of what they earn, and for women there is part of what they earn, and ask God of some of his gifts. Allah is All-Knowing all things.

\footnotetext{
3 'Ali ibn Ah\}mad Al-Wah\}idi>, Alwaji>z fi> al tafsi>r AlKita>b al-'Azi>z, Vol. 2, (Beirut: Da>r
} alQalam alDa>r alSyamsiyah, t.th.), p.1019. 
This verse explains For men there is a part of what they do and for women there is also a part of what they try. Therefore the Qur'an forbids that both sexes are not envious of the results of their efforts. ${ }^{4}$

More explicitly again the Qur'an through verse 35 of the letter al ahzab explain the equality between men and women from the internal perspective of Muslims by stating

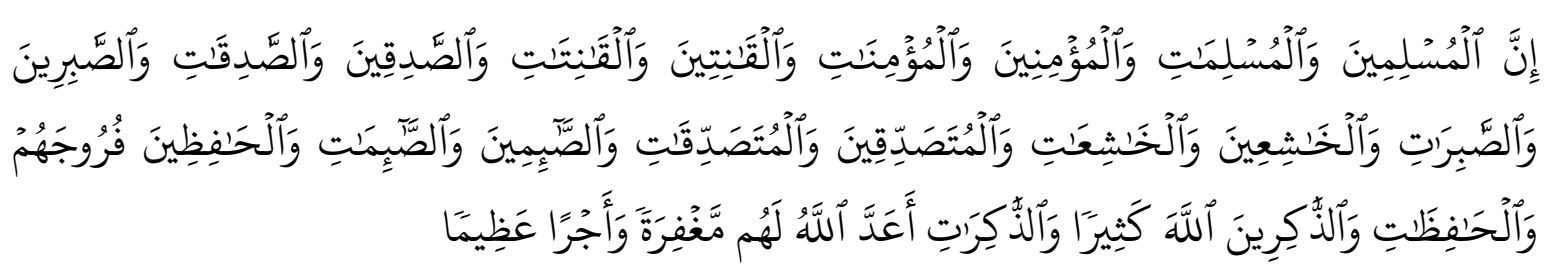

Truly Moslem men and women, faithful men and women, men and women who remain in obedience, the right men and women, men and women who are patient, men and women who are solemn, charity men and women, fasting men and women, men and women who nurtured their honor, men and women who many call (name) Allah, Allah Has provided for them forgiveness and great reward. ${ }^{5}$

The creation of man on earth aims to be in addition to being a submissive and obedient servant to God as well as a khalifa fi ardh. This explanation is found in Q.S.2: 30:

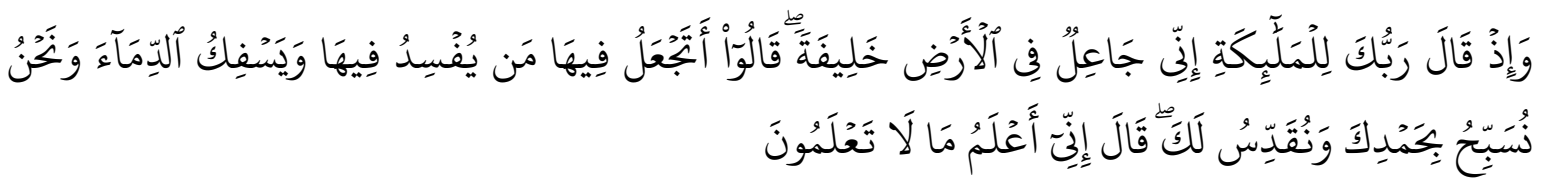

Remember when your Lord said to the angels: "I will make a caliph in the earth." they say: "Why would You make the (Caliph) on earth the one who will make the damage to him and shed blood, but we always celebrate by praising You and sanctifying You? "The Lord said:" Verily I know what you do not know."

And also Q.S.6: 165

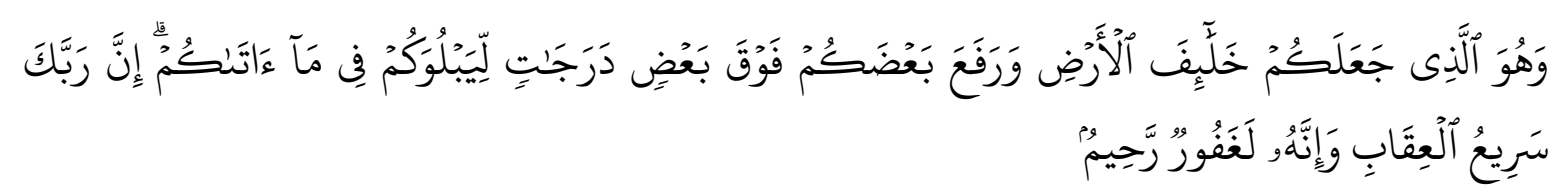

And he is the one who made you rulers of the earth, and he exalts your height on some (others) a few degrees, to test you of what He has given you. Verily thy Lord is very torture, and verily, he is Oft-Forgiving, Most Merciful.

${ }^{4}$ Imam Al-syaukani, Fath\}\} u alQadi>r, Vol. 5 (Beirut: Dar alfikr, t.th), p. 67.

${ }^{5}$ AlIma>m Abu> Muh $\}$ ammad AlBagha>wi> in his book $M a$ 'a $>$ lim altanzi>1, Vol. 2, p. 529, explains this verse came down to answer the objections of Asmak bint Umais returning from Ethiopia with her husband Jafar ibn Abi Talib who when returning from Ethiopia met the wives of the prophet and asked: is there a Qur'an coming down about us? They answered no. He then listed the Messenger (Rasul) and commented that in fact women were in a position of disappointment and loss. The Messenger asked: Why is that? He answered because women are not called the same as men about kindness. Then this verse comes down to answer it. 
The word caliph on these two verses does not refer to any of the sexes. Both men and women have the same function as caliphs who will also bear the task before the divine as a servant of God on the day of vengeance later.

Here are some verses of the Qur'an explicitly explaining equality between men and women in the sight of God. However, when explaining the relationships between men and women in the context of social politics and law of the Qur'an impressed men put a degree above women.

\section{Male is higher than women}

There is a difference of views in the interpretation of the relation between male and female in the view of classical and modern scholars. The difference occurs in looking at the word qawwamun in the 34th verse of the letter of Alnisa. ${ }^{6}$

\section{Classical Ulama View}

The classical scholars shifted the meaning of al-qawwāmah in various contexts of life. In other words that al-qawwāmah according to classical scholars applied in general. It differs from the interpretation and understanding of modern scholars who apply the meaning of al-qawwāmah in only in certain contexts. It is based on the cause of the verse, when a woman complains to the Prophet the wife has been slapped by the husband. then the Prophet ordered qișas. But Allah SWT down this verse annulled the decision of the Prophet SAW. This means that this verse is seen as the legitimacy of the husband's leadership of the wife in the household affairs. While the issue of leadership in the public domain, women's rights can not be limited by using this verse. ${ }^{7}$

Fakhru ar-Rāzi and other classical mufassirs argue that leadership recommendations given to men are based on two major considerations: First, because men and women are each considered to have advantages. Second, men are charged with the responsibility to provide for their wives and not vice versa. The mufassirs realize that the phrase explains that men and women each have advantages, but in the context of the family, some of the advantages that men have are seen to be more supportive of leadership tasks. While from the classical put forward the privileges and advantages possessed by men.

Similarly, classical scholars such as ar-Razi on the advantages and virtues of men over women mention that the privileges and virtues lie in the original character and attributes (asșifāt al-haqīiyyah) which are based on two things: ability (qudrah). In his commentary, arRāzi states, "There is no doubt that intellect, logic, intellectuality and men's scholarship are above women. The ability (qudrah) of men to do hard work is more perfect and stronger than

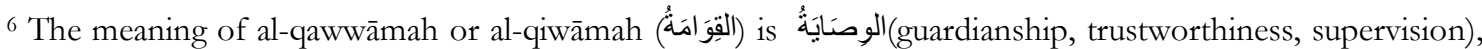

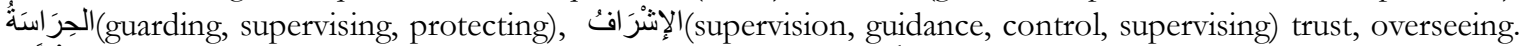

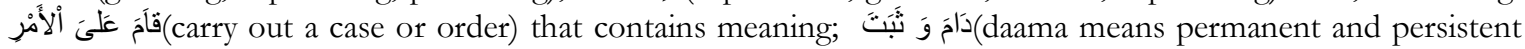
while tasabata is sturdy, stable, unchanging, constant and certain). responsible for the affairs of his family giving their livelihoods). Abdurrah \} man Abdul Mun`im, Mu“ jam al-Must\}alahāt wa al-Alfāẓ al-Fiqhiyyah (Cairo: Dār

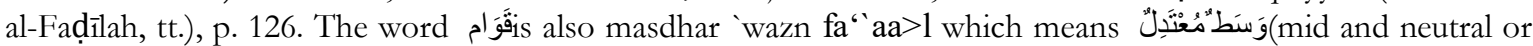

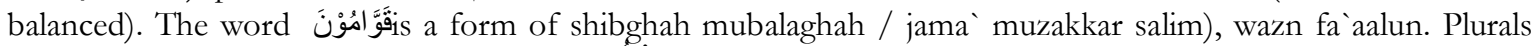

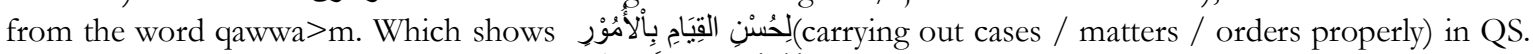

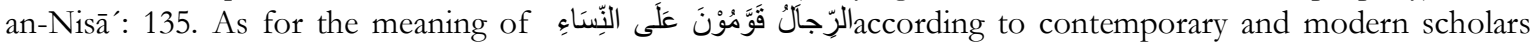
including Rashid Rida (1865-1935 AD), As-Sya“"rāwi> (1911-1998 AD) the meaning is as follows:

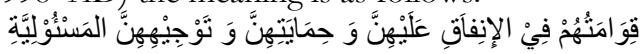

(male responsibility for his wife in providing support, protection and directing and guiding them to take responsibility).

${ }^{7}$ Faisar Ananda Arfa, Wanita Dalam Konsep Islam Modernis (Jakarta: Pustaka firdaus, 2004), p. 174; Fakhru arRazi, At-Tafsir al-Kabir (Kairo: Maktabah at-Taufiqiyah, 2003), Vol. 10, p. 80.
} 
women. It is on this basis that men find fadilah (superiority or virtue) above women both in terms of reason, firmness and wisdom / hazm and strength, writing in various foreign languages such as Persian and Roman. Not only that, even the prophets, scholars of the men. In terms of male leadership which is charged to hold imāmah kubrā and imāmah șugrā. Similarly, in terms of jihad, azan, khutbah, 'itikāf, witness ḥudūd and qișaș, marriage according to as-Sūfi i RA, addition of inheritance and become` așābah, charging diyat killing and killing, qasāmah and marriage trust, talak and polygamy and nasab determined from the male line. All this shows the strength or the position of the male over female. ${ }^{8}$

The interpretation of surah an-Nisā 3 indicates the absolute position of men as leaders in the family. Ibn 'Abbas, interpreted that the husband is the one who has the power and authority to educate the wife. So the position of women is as subordinate of the leader in the household that is the husband. The phrase الرجال قومون على النساءby Al-Thaba>ri (w.932 AD) in his commentary explained that, "Men functioned to educate and guide their wives in performing their duty to God and husbands." Al-Zamakhsyari (d. $1143 \mathrm{CE}$ ) interprets the phrase with "men functioning as governing and forbidding women as leaders function against their subjects. By this function men are named qawwam. "As for al-Rāzi (w.1210 AD) this phrase means," men have power to educate and guide their wives, as if he the Most High makes husband as emirs and law enforcers regarding the rights of wives. Ibn Kasīir (w.1373 AD) explains, "The husband is the qayyim of the wife in the sense that he is the leader, the ruler, the ruler and his educator, if the wife is bent" while al-Alūsi interprets, "The duty of men is to lead the people women as leaders lead their people by command, prohibition and so on."

Ibn 'Abbās (w 619-687 AD) explains the reason for descending QS. An-Nisā ': 34, he said, "This verse goes down to the daughter of Muhammad ibn Salamah who married Sa ad bin Ar-Rabi" one of Anșār's rulers. Sa 'ad has slapped his wife and his slap is still visible on the cheek of his wife. Then Rasulullah PBUH said:

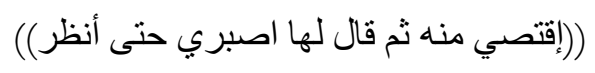

"Make Qis\}as\} for your husband. Then Rasulullah SAW said to the danghter of Mubammad bin Musallamah, "Be patient with you until I know." Then came the verse of الرجال قومون على النساء which means that men in power, have authority and power (sul'ah) over all acts and behavior of women and men are policymakers above the women. Ibn 'Abbas adds, as if this verse makes man as king (amir) for women and the executor of his right law. When the passage of this verse an-Nisā ': 34, the Messenger of Allah (PBUH) said:

$$
\text { ("أردنا أمر او أراد الله أمر ا والذي أراد الله خير") }
$$

"When we want a case while God wants another thing and what God wants is better." Finally the Prophet (s) lifted the verdict of qișaș.

Because down verses described above, shows that the position of men in the household is higher than women. So the woman (wife) should not avenge harsh treatment (meng-qishash) her husband. The reason male position is higher than women here is because Allah SWT has established male power over woman and take care of woman. According to Ar-Rāzi it is based on two factors, first because بما فضل الله بعضهم على بعض second, due to وبما From the view of Fakhru ar-Rāzi it can be seen that men's position is more affective than women because men are given fadl by Allah SWT in the form of privileges and advantages and secondly for giving dowries and living. The concept of al-qawwāmah based on

${ }^{8}$ Ar-Razi, At-Tafsir al-Kabir, p. 80.

9 Yunahar Ilyas, "Kepemimpinan dalam Keluarga: Pendekatan Tafsir dalam Wanita dan Keluarga: Citra Sebuah Peradaban", Jurnal Al-Insan, Number 3, Vol. 2, 2006, p. 30.

${ }^{10}$ ar-Rāzi, At-Tafsì al-Kabir, p. 80. 
these two factors indicates that the position of women is under men in all aspects, whether in the household or outside the household.

In accordance with the above statement, Ibn al-Qayyim $(691 \mathrm{H} / 1292-751 \mathrm{H} / 1350$ $\mathrm{AD})$ mentions that women under male rule are based on the concept of al-qawwamah. In his statement depicting the woman's position on the basis of the reality that occurred during her lifetime (asru al-mamlūk / Mamalik Dynasty) she mentioned," Surely a lord has dominion over her possessions, has authority and authority over her and become her king. Similarly a husband qāhir (ruling) over his wife and have authority over it (hākim `alaihā). The wife under his control, his law or his position is like an athande (prisoner). "That is the meaning of alqawwāmah to the relationship between husband and wife according to him at that time. ${ }^{11}$

Similarly, the above statement mentions other scholars such as Az-Zamakhsyari and Jalāluddīn as-Suyūṭi (849 H / 1445 M-911 H / 1505 CE) who also argue that men have dominion over women so that the position of men higher than women. In his opinion, about the position of women, az-Zamakhsyari which explains that men are obliged to perform amar ma'rūf and nahi munkar to women. Az-Zamakhsyari mentions that the position of men with women as well as the ruler with his people. Likewise with Jalaluddin as-Suyuthi who interpret the concept of al-qawwāmah this by mentioning that men as rulers (musallițūn) over women and Ibn Kasīir interpret the position of women based on the concept of al-qawwāmah this by mentioning that men are as leaders, people who are elderly (respected) and as policymakers for women."12

\section{The Modern Ulema View}

Not surprisingly different from the classical scholars that the authors describe above, modern-day clerics such as Shaykh Mutawalli Sya rāwi, Muhammad Ali al-Sayis, Yūsuf alQarḍāwi and mufassir homelands like Muhammad Quraish Syihab also stated that the position of men above the position woman. In other words, that the position of women under male status. What distinguishes the meaning of women's position with other men between classical and modern scholars although the same context that the position of women under male status ie as the leader is a function of male leadership over women. Modern scholars mention the context of leadership here is the cooperation between husband and wife and the division of tasks respectively.

Sya rāwi states that the meaning of al-qawwāmah in essence does not mean men have a more important position than women but the division of tasks, where each person is assigned to do one job, then he will try and focus all his efforts to carry out the task well. Concerning the concept of al-qawwamah, Sya rāwi states that in fact the word stand (al-qiyām) is mentioned in the QS. An-Nisā ': 34 is the opposite of the meaning of sitting (al-qu 'ùd). Based on his interpretation, Sya rāwi argues that what men mean as leaders are men as drivers of the wheel of life in order to cover all the needs of the women, preserve them, and fulfill all their demands in the form of matter and food. So, what is meant by leaders here is a responsibility to meet the needs of his wife and children. ${ }^{13}$

From the statement it can be understood that Sya rāwi agrees with the opinion of the classical scholar who mentions the meaning of al-qawwāmah is the leadership in which the

${ }^{11}$ Imārah, Haqāiq wa Syubhāt, p. 160.

12 Az-Zamakhsyari, al-Kasysyaf 'an Haqaaiq at-Tanzi>l wa 'Uyun al-Aqa>wil fi Wuju>hi at-Ta' wil (Beirut: Da>r al-Kutub al-'Arabiyah, t.th.), vol. I, p. 523; Jalaluddin as-Suyu >t $\}$ i $>$, Tafsi $>$ r al-Jala $>$ lain (Surabaya: Sa>lim Nabha>n, 1958), p. 44; Abu al-Fida`Ibnu Kaslir, Tafsi>r al-Qur`an al-Az\}im (Kairo: Mat\} ba“'ah Istiqa>mah, t. th), p. 491.

${ }^{13}$ Mutawalli Sya`rāwi, Fiqh al-Mar 'ah al-Muslimah, terj. Yessi HM. Basyaruddin (Jakarta: Amzah, 2009), p. 168. 
position of man is above the woman's position. The difference is the reason for his leadership, which according to Sya rāwi a leader is a person who is ready to stand, must be strong because standing work is not an easy thing. Leaders should be able to withstand fatigue and who can withstand fatigue and tired of the lead is male. Regarding the difficulty of holding the leadership wheel, in his statement, Sya rāwi adds that when the policeman says he is the leader of a people, and in the household, the husband is the leader, he must be ready because in his tenure he will always feel tired. ${ }^{14}$

In line with the above opinion, Muhammad 'Ali al-Sayis holds that QS. An-Nisā ': 34 speaks of the position of men as female leaders. However, the leadership in this verse speaks specifically in the context of family affairs, he elaborates in his commentary, Allah Almighty puts the right of "leadership" (al-qiyām) in the sense of responsibility to preserve the family's survival and welfare to the husband. The same reason First, there are advantages that men have over women, namely intelligence of mind, physical strength and the firmness of ideals and will. On the basis of this privilege, the only man appointed to be the prophet and apostle, who is entitled to be the head of state (Ima $>$ mah al-kubra) and other officials (imāmah as-ugūr), acts to uphold the religious syariah, such as the azan, iqāmah, khutbah jum at, jihad and rights for divorce and reconciliation, right nasab, permissibility polygamy and excess portion in inheritance and so on. Second, the obligation to provide dowry, livelihood, clothing, food and boards. ${ }^{15}$

Yūsuf al-Qarḍ̄âi gives different reasons for the position under male status. According to Yūsuf al-Qarḍ̄awi the position of women under male leadership is not due to such features nor is it because God overwhelms men over women but the reason is as mentioned in the verse al-qawwāmahitu itself namely,

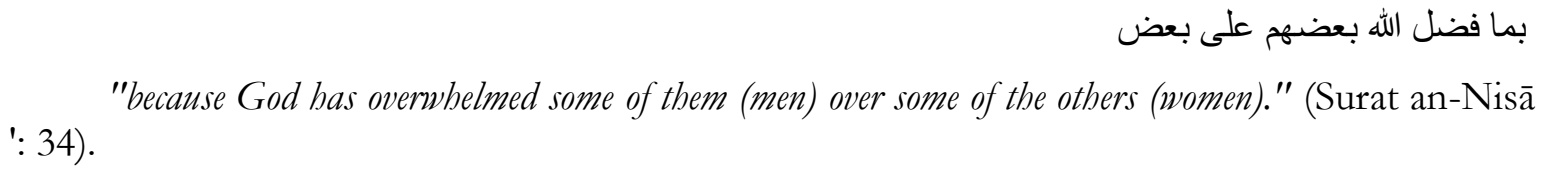
': 34).

Based on Allah's statement above, according to Al-Qardāâwi the position of women under the leadership of men in the household is not because of the privileges and advantages because men and women are equally given their own advantages and privileges. women are given the advantage in some aspects and men are also given the advantage in some other aspects. ${ }^{16}$

It is different in al-Qardāwi's view of the position of women in issues outside the home (public domain). Yùsuf al-Qardāaiwi views the position of women in the political system for example, women's position as well as men. al-Qarḍāwi aligns women with men, because in political matters both have equal rights, have full rights to vote and the right to be elected. According to al-Qarḍāwi, adult women are fully mukallaf (given responsibility) men, who are required to worship God, establish religion, perform duties, stay away from his prohibitions, preach for his religion, and are obliged to do amar ma rūf nahi munkar, as well as men, as well as in matters relating to state affairs.

Quraish Shihab in tafsir al-Mișbāh also states the male leadership over women. In other words, the position of woman (wife) is under the leader (husband) as as-Sayis which

${ }^{14}$ Ibid., p. 169.

15 Amiur Nuruddin, Jamuan Ilabi Pesan Al-Qur'an dalam Berbagai Dimensi Kehidupan (Bandung: Citapustaka Media, 2007), p. 149.

${ }^{16}$ Amrū ‘Abdul Karīm Sa dāwi, Qaḍāyà al-Mar’ah fì Fiqhi al-Qanḍawwi, trans., Muhyiddin Mas Rida, Wanita dalam Fiqih al-Qandāwi (Jakarta: Pustaka Al-Kautsar, 2009), p. 111. 
mentions the existence of men's privileges than women are psychic or the ability and strength of men is according to Quraish the privilege of men is because men provider.

In Tafsīr Al-Mișbāh, Quraysh Shihab presents his account of the concept of alqawwāmah mentioned in the QS. An-Nisā ': 34, he says that the word qawwāmūna is in line with the meaning of the word ar-rijāl which means many men. Quraish considered that the leadership contained in the verse should include the fulfillment of needs, concerns, care, defense, and pembinaa. So the reason for male status as leaders according to him, is because the privilege that men have more supportive of leadership tasks than the privilege of women. ${ }^{17}$

Among the features of men is the breadwinner. It is understood from the phrase أنفقو المن أموالهم (and what they spend from their wealth). The past verb (fi'il mādi / past tense) used in this phrase, أنفق أن (has spent) shows that giving a living to women has become a norm for men and is a common fact in various societies from the past to the present. Meanwhile, the privileges that women have more support their duty as a pacifist and peace of mind to men, and more support its function in educating and raising children. According to Quraish, the superiority or virtue of men's position over women is based on many aspects, among them is haqiqi (fact) aspect while the other aspect is syar $i$ aspect (law). ${ }^{18}$

From the above opinion it is clear that the classical and modern scholars have similarities in interpreting al-qawwāmah ie leadership. Where men become female leaders so that the position of women under male leadership. The difference is that the classical scholar was influenced by the socio-cultural of his time in which the position of women was under the full power of men. In other words the absoluteness of leadership here in all aspects of life and dihapami and applied in general. Even as the classical scholars describe the position of women lower than women, they reveal that the position of women with men is like a ruler with his subjects, the leader with his subordinates is even lower than that mentioned by Ibn al-Qayyim which describes the position of women in his day like a prisoner with his master.

In contrast to the concept of al-qawwāmah adhered to by modern scholars, according to them even though men are higher or above women, but the concept of leadership here is cooperation and mutual respect and modern scholars view the conception of al-qawwāmah here in understanding and special application that is in household aspect. Husband becomes a leader to maintain the continuity and prosperity he leads. Although modern scholars differ on the reasons for male leadership. Among them, such as Yūsuf al-Qarḍāwi who does not look at the features and virtues of men because each man and woman have privileges. While modern scholars see the primacy and privilege of men over women so that men are more worthy of female leaders, such as Muhammad 'Ali as-Sayis which is more of a physical form, while other commentators such as Quraish Shihab view the existence of privileges and virtues male.

Especially nowadays women have the same position with men in various fields of education, employment, scientific field, sports field and so forth. Women are now no longer confined within the home, but have been out, entering the broad public sector, side by side with men in Lembanga-educational institutions, offices, shops, hospitals, research, sports, military and employment others. ${ }^{19}$ Thus, there is no factor that can be used as an excuse not to allow women to work and to choose a job and even hold the highest position even in their career during the work is halal and the maintenance of the boundaries of the Shari'a.

The first sentence descended in the Qur'ann is the sentence of the command to read (iqra '), then followed by God's first oath in the Qur'an is "Nūn. For the sake of kalam and

\footnotetext{
17 M. Quraisy Shihab, Tafsir al-Mișbah (Jakarta: Lentara Hati, 2009), p. 511-512.

${ }^{18}$ Quraisy Shihab, Tafsìr al-Mișbäh; Pesan dan Keserasian (Jakarta: Lentera Hati, 2000), Vol. II, p. 408.

${ }^{19}$ Harun Nasution, Islam Rasional Gagasan dan Pemikiran (Bandung: Mizan, 1998), p. 240.
} 
what he wrote. "This confirms the importance of science in Islam. The command to demand knowledge not only in men but also in women, as affirmed in a popular tradition in society, that is, "to demand science is obligatory for male and female Muslims." ${ }^{20}$

The Qur'ān and hadith give many praises to men and women who have achievements in science. In a narration it is mentioned that the Prophet was visited by a group of women who requested the Prophet's willingness to set aside his time to gain knowledge. In classical Islamic history is also found some of the names that dominate the sciences such as 'Âisyah the wife of the Prophet, Sayyidah Sakinah daughter Husain bin' Ali bin Abu Țalib, al-Shaykh al-Suhrah who is dubbed "Fakhr an-Nisā" (pride of women), is one of the teachers of the Imam of Shafi'i, Mu'nisāt al-Ayyūbi (brother Șalāhuddīn al-Ayyūbi), Shāmiyāt at-Taimiyah, Zainab (daughter of historian al-Baghdādi), Rabī’a al-'Adawiyah and so forth. The freedom of women in the study of science is explained in many traditions, as hadith narrated by Ahmad that the Messenger of Allah cursed women who made a likeness to men, and vice versa, but not forbidden to make similarities in the intellect and charity of ma ${ }^{\text {ruf. }}{ }^{21}$

The concept of al-qawwāmah according to classical and contemporary scholars has implications for the position of women in the household and outside the household. From the exposure of the opinions of scholars the writer considers that al-qawwāmah according to contemporary scholars or modernists are distinguished in social, political and family contexts. In this case it is seen that in two contexts, namely in the domestic (family) and the public (outside the household) areas including the social and political context.

The social and political context of the public domain is the domain of disagreement between classical and contemporary clerics. Where classical scholars do not distinguish the application of the conception of al-qawwamah. According to them that the concept of alqawwāmah is applicable in every line of life and in the social, political and family context. Thus, leadership only applies to men. In contrast to scholars and fuqaha century modern and contemporary. Where they distinguished the conception of al-qawwāmah in public and domestic territory. In the public domain according to contemporary scholars the position of women is not as in the domestic territory. Because in the public domain women have the right to participate and participate in the social or political sphere and work to help the husband and improve the standard of family life. Thus, in the context of the public domain the woman has the right to be a leader outside her household.

While this family context is the point of equality between the views of contemporary scholars, modernists and classical scholars about the concept of al-qawwāmah (leadership) is only recommended for men. In the context of this family the contemporary and classical scholars agree on the absoluteness of male leadership in the family context. This has an effect or implication for the position of women in Islamic law. In the context of this family, the dominance of men as leaders is particularly striking as the marriage of women should be with their guardians who result in sometimes the wali who holds the power and choice for the woman he represents, the obedience of the wife who must be ready to serve the sexual husband in any condition whether being menstruating or no. During menstruation women still have to be able to serve the husband, and husband is legally allowed bertamattu ' with his wife who menstruate but limit tamattu 'area that is not allowed. The above exposures indicate that male dominance over women, in which the position of men is higher than that of women. Because the husband is the leader. Which certainly has power, authority against women. So it seems clear in the literature or the words and opinions of ulama and fuqaha strongly emphasized the concepts mu'amalah well to behave with ma'rūf to women (wife). It appears that scholars and fuqaha adopted this concept in the family realm as well as the orders and

${ }^{20}$ Ibid., p. 317

${ }^{21}$ Nasaruddin, Akblak Wanita, h. 318. 
rules of the Shāri, also aimed at making the yellow light to husbands to be careful and behaving well, to intercourse wives with ma'rūf and not to use power, authority and do harshness.

Unlike the case of modernist ulema such as Muhammad 'Abduh. Despite Muhammad Abduh from contemporary scholars, his opinions are more modern and different, both with other contemporary scholars especially with the classical scholars. This is because according to Muhammad 'Abduh this al-qawwāmah conception is not absolute. So that male leadership is not absolute in the domestic (family) and the public (social and political context).

\section{New Perspectives in Reading the Sacred Text}

In subsequent developments, enthusiasts of Islamic studies provide a new color in how to read the existing text so as to impress the new way of reading produces a slightly different understanding but gives considerable implications for the understanding of relations between men and women in the perspective of the ahkam interpretation.

Azizah AlHibri in his article entitled Islam, Law and Custom: Redefining Muslim Women's Right offers a new perspective on reading the sacred texts on gende relation above. According to him, many Muslims who may not agree with the argument which he proposed. Likewise, the disagreement is not surprising given that even the views of previous scholars are often matched by their contemporary, The best way to resolve the differences has actually been taught by the Qur'an in al-verse 59 of the letter that if people believe differing opinions about something then they must seek answers to the Qur'an and the sunnah of the Prophet. ${ }^{22}$

According to alhibri, all Muslims agree that the Qur'an is rich in meaning. Even the structure of the truth of the Qur'an is absolute as well as dialectical. Its absoluteness is Kalamullah, but it is also dialectical because our growing humanitarian awareness captures that absolute truth in the dialectical scene grows in line with our growing belief. The Qur'an recognizes human limitations in its methodological issues. Revealed gradually and its ban is also applied gradually. Other prohibitions and fundamental changes such as women's affairs and slavery were introduced for the results to be achieved over a period of time. Part of the philosophy of the Qur'an is not only based on the principle of gradualism in social change but also part of the sky's policy in the face of humanitarian democracy, ie the collective ability of the people to make their own choices. Otherwise, it means God has from the beginning rejected all the freedoms of human choice and instead imposed all truth upon them. This conclusion contradicts the Qur'anic claim that there is no compulsion in religion Q.2: $256 .{ }^{23}$

An example is that the Qur'an does not hastily prohibit slavery in one situation when the world relies heavily on enslavement economically. As a replacement. The Qur'an lays down the principles and rules of rule that if followed by pious Muslims will totally abolish slavery within a generation or two in the future. The fact that the world in general and Muslims in particular takes several centuries to achieve the idealism of Islam to abolish slavery gives an idea of how deep it is in the world community and how long changes are needed to achieve it. ${ }^{24}$

Therefore, according to alibib, it is very important to understand the world view of the Qur'an in an attempt to try to capture the absolute truth in it that we need to guess its presence in our present world. The central concept in the Qur'an is monotheism ie there is

22 Azizah al-Hibri, “Islam,Law and Customs: Refedining Muslim Women’s Rights”, American University Journal of International Law and Policy, Washington College Law, vol.12, no.1.p. 25.

${ }^{23}$ Ibid.

${ }^{24}$ Ibid.,p. 26. 
only one supreme being namely God. It is this concept that floods the whole Qur'an. Al-Hibri made the fall of Satan his approach. According to the Satanic Qur'an falling from the glory is the result of his narcissism. Only he who refuses to obey God's commands is respectful of Adam. In his rejection he said: "I am better than he; You created me from fire while he was from the ground (Q.7: 12). This statement traps the essence of demonic logic based on the feeling of the narcissistic and superior being imagined to be between God and his creation. ${ }^{25}$

Al-Hibri concludes that arrogant Muslims, whether for individual reasons, racial, economic or gender relations have been caught up in the logic of Satan. The Qur'an states clearly and repeatedly that all human beings are created from the same soul (Q.4: 1.6: 98,7: 189). In particular the first verse of the letter alnisa reads:

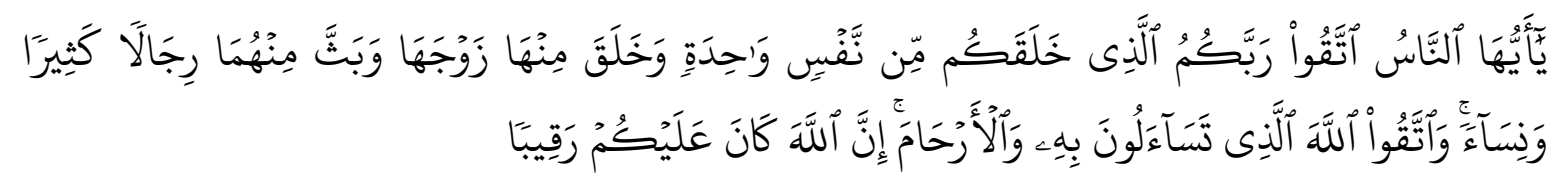

O ye people, fear your Lord Who created you from a single self, and from him God created his wife; and of them God has multiplied many men and women. and fear Allah who by His name you ask one another, and (nurture) the relationship of silaturrabim. Allah always guard and keep watch over you.

The question that arises from this verse is: When humans are all created from the same soul, why did God create so many of us? Again the Qur'an provides answers. Associated with race and ethnicity? The Qur'an states that humans are created in various tribes and nations to get to know each other. Regarding gender, the Qur'an states in the letter alRum that God created man of your own kind so we can find serenity. There is indeed a sign for those who think. This pattern of gender relationship verses is repeatedly mentioned in the Qur'an. AlHibri then concludes that this is a general basic principle of proper gender relations, namely that the relationship of men and women is to find compassion based on love. This kind of relationship does not give space to the devil's hierarchy that often gives rise to oppression and suppression. ${ }^{26}$

Concerning the 34th verse of the al-Nisa's letter on the word qawwam, alHibri states that this word has many meanings, hence it prefers a meaning which does not contain the connotation of hierarchy. While the word faddala also does not describe the advantages of men against women. Because it is associated with the word bi ma. Thus according to his translation the verse is: "Men are (advisors / providers of guidance) to women (because / in circumstances where / in that which) God made some of them different from some others and (because / in circumstances where / in that which) they spend their own money. ${ }^{27}$

According to alHibri, the Qur'anic verse on the principle of equality is general and has no qualifications and requirements and is also repeated many times in the Qur'an. While the complex verse begins with the general statement "arrijalu qawwamuna ala alnisa" and followed by an explanation that serves to limit the announcement of the statement (takhsis ala al 'am) by specifying a reason or condition (bima) that will support a man as a qawwam. It also includes the differences between men and women. ${ }^{28}$

There are two elementary restrictions. Firstly that men as qawwamun to women is a general statement that applies only when God gives to a man one ability and character that a woman does not have in one particular circumstance and a man protects and guards the woman. The first element is important to explain why the role of male advisory is accepted as

${ }^{25}$ Ibid., p. 26.

${ }^{26}$ Ibid., p. 27.

${ }^{27}$ Ibid., p. 29.

${ }^{28}$ Ibid., p. 29. 
a whole. The second element is important to limit the role of male advisory that has previously been protecting women as their protector. If not then women can reject the role of the man. ${ }^{29}$

The Qur'an clearly indicates that not all men meet both of these requirements. One of them the word "bima" indicates some men not all. The subsequent text again reinforces the fact with the word "ba'dahahum which is partially meaningful. In other words the Qur'an describes (not recommending) in this verse a situation similar to the tradition that existed at that time when some women were financially bound. Under these circumstances the verse informs that God imposes upon men the responsibility of women to offer guidance and advice in areas where men are more seasoned and experienced. Likewise the woman has the right to refuse.

To support his thesis alHibri quotes alRazi a famous scholar of the 13th century who discussed the word bima. According to alRazi the word bima has one of two meanings: (a) Bima means "who is". Ma here acts as a pure liaison.

(b) Bima with Masdariyah function with Sababiyah meaning.

According to alibhi language analysis shows that complex phrases create perfect flavor. Even if the conclusion is true, the phrase about ali'wamahs may be possessed by certain women against certain men in conditions similar to the above conditions will occur theoretically from that point. Likewise, if at any point it becomes important to discuss symmetrical responsibilities between men and women, the Qur'an will not hesitate to fulfill it. The Qur'an has declared male and female believers to be their interfaith carers. (Q.9: 71). It is important to emphasize this verse as an appropriate foundation for gender relations for today's Muslim society. ${ }^{30}$

The complex phrase has been revealed to a patriarchal society that the Prophet tries to cultivate and democratize. Consequently, this is viewed in reality. This becomes a limitation for men who prevent them from assuming automatically to suppress the authoritarian role associated with women. At its peak, this complex phrase tells them that they can be a pointer and advisor to women they support financially and only when certain conditions are met. The rest of this verse does not alter this analysis even if one tries to analyze it from a nonpatriarchal point of view. ${ }^{31}$

\section{Conclusion}

The concept of gender relations in the Qur'an reflects two distinct impression theologies and sociologists. Theologies of the Qur'an imply a plain view that both men and women have equal standing in access to God. But sociologically the Qur'an gives a higher degree of women. This degree does not reflect the glory but rather the responsibility and burden that is given to the male's shoulder in the household in the form of a livelihood burden. The consequence is of course the classical mufassir asserted that social leadership is also given to men. Slightly different from classical scholars, contemporary scholars argue that there is no prohibition for women to compete in social leadership outside the home.

\footnotetext{
${ }^{29}$ Ibid., p. 30.

${ }^{30}$ Ibid., p. 32.

${ }^{31}$ Ibid.
} 


\section{REFERENCES}

Al-Aridl, Ali Hasan. 1994. Sejarah dan Metodologi Tafsir. Jakarta: PT Raja Grafindo Persada,

AlBaghawi, AlImam Abu Muhammad. 2015. Máalim altanæil, Vol. 2. Beirut: Dar al-Kutb 'Ilmiyyah.

al-Hibri, Azizah. "Islam,Law and Customs: Refedining Muslim Women's Rights", American University Journal of International Law and Policy. Washington College Law, vol.12, no.1.

AlImam AlSyaukani. t.th. Fathu alQadir. Vol. 5. Beirut: Da $>$ r alfikr.

Al-Wahidi, 'Ali ibn Ahmad. t.th. Alwajiz fi al tafsir AlKitab al-'Aziz, Vol. 2. Beirut: Dar alQalam alDar alSyamsiyah.

Arfa, Faisar Ananda. 2004. W anita Dalam Konsep Islam Modernis. Jakarta: Pustaka firdaus.

as-Suyuti, Jalaluddin. 1958. Tafsir al-Jalalain. Surabaya: Salim Nabhan.

Az-Zamakhsyari. t.th. al-Kasysyaf 'an Haqaaiq at-Tanzil wa 'Uyun al-Aqawil fi Wujubi at-Ta' wil. Beirut: Dar al-Kutub al-'Arabiyah.

Fakhru ar-Razi. 2003. At-Tafsir al-Kabir. Kairo: Maktabah at-Taufiqiyah.

Ilyas, Yunahar. 2006. "Kepemimpinan dalam Keluarga: Pendekatan Tafsir dalam Wanita dan Keluarga: Citra Sebuah Peradaban., Jurnal Al-Insan, Number 3, Vol. 2.

Kasir, Abu al-Fida`Ibnu. Tafsir al-Qur`an al-Az̧im. Kairo: Matba“ah Istiqamah, t. th.

Mun“im, Abdurrahman Abdul. tt. Mu“jam al-Mustalahät wa al-Alfäz al-Fiqhiyyah. Cairo: Dar alFadịilah,

Nasution, Harun. 1998. Islam Rasional Gagasan dan Pemikiran. Bandung: Mizan.

Nuruddin, Amiur. 2007. Jamuan Ilabi Pesan Al-Quran dalam Berbagai Dimensi Kebidupan. Bandung: Citapustaka Media.

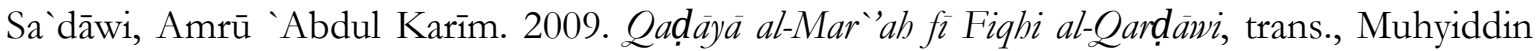
Mas Rida, Wanita dalam Fiqih al-Qandanwi. Jakarta: Pustaka Al-Kautsar.

Shihab, M. Quraisy. 2000. Tafsìr al-Mișbāh; Pesan dan Keserasian. Jakarta: Lentera Hati. . 2009. Tafsir al-Mișbah. Jakarta: Lentara Hati.

Bandung: Mizan,

Sya’rāwi, Mutawalli. 2009. Fiqh al-Mar”ah al-Muslimah, trans. Yessi HM. Basyaruddin. Jakarta: Amzah. 